\title{
Influence of heat treatment medium on properties of the bovine hydroxyapatite/magnetite systems
}

\author{
Oksana Otychenko ${ }^{1}$, Tetyana Babutina ${ }^{1}$, Anatolii Perekos ${ }^{2}$, \\ Oleksandr Bykov ${ }^{3}$, Sergiy Korichev ${ }^{3}$, Oleksandr Koval ${ }^{4}$
}

\footnotetext{
${ }^{1}$ Frantsevich Institute for Problems in Materials Science of NAS of Ukraine, Department of Functional Materials for Medical Application, 3, Krzhizhanovsky str., 03142, Kyiv, Ukraine.

${ }^{2}$ Kurdyumov Institute Of Metal Physics of NAS of Ukraine - Department of Constitution and Properties of Solid Solutions,36 Academician Vernadsky Boulevard,03142, Kyiv, Ukraine.

${ }^{3}$ Frantsevich Institute for Problems in Materials Science of NAS of Ukraine, Department of Physical Material Science of Refractory Compounds, 3, Krzhizhanovsky str., 03142, Kyiv, Ukraine.

${ }^{4}$ Frantsevich Institute for Problems in Materials Science of NAS of Ukraine, Department of Physics of Strength and Plasticity of Materials, 3, Krzhizhanovsky str., 03142, Kyiv, Ukraine.

e-mail: oksanaotychenko@gmail.com, babutina@ukr.net, perekos@ukr.net, pavelBykov1@gmail.com,

sergey_korichev@ukr.net
}

\begin{abstract}
Technological processes for the synthesis of composite systems based on bovine (rather than synthetic) hydroxyapatite are rarely described. That's why the influence of the heat treatment medium on the properties of the composite system bovine hydroxyapatite/magnetite $\left(\mathrm{BHA} / \mathrm{Fe}_{3} \mathrm{O}_{4}\right)$ obtained using physico-mechanical and chemical methods were investigated. It was established that the most efficient medium for heat treatment of studied materials is vacuum. Due to XRD analysis data allow us to assert that the most perfect lattice is formed with the use of the chemical method for production and heat treatment in a vacuum (crystallinity $86 \%$ ), and the least perfect one is formed by the mechanical method for production and heat treatment in a nitrogen medium $(71 \%)$. The method for adding magnetite has only a minor effect. Investigated conditions of heat treatment of composite systems $\mathrm{BHA} / \mathrm{Fe}_{3} \mathrm{O}_{4}$ promoted obtaining optimal magnetic properties and stable behavior in experiments in vitro.
\end{abstract}

Keywords: bovine hydroxyapatite, magnetite, crystallinity, specific saturation magnetization, in vitro experiments.

\section{INTRODUCTION}

The before carried-out studies of the composition, structure and properties of bone tissue and its recovery mechanism have provided the success in using bioactive calcium phosphate based ceramics. Of the large number of bioceramic materials, two phases are most biocompatible, namely $\beta$-Ca $\left(\mathrm{PO}_{4}\right)_{2}(\beta$-tricalcium phosphate, in short $\beta$-TCP) and hydroxyapatite $(\mathrm{HA}) \mathrm{Ca}_{10}\left(\mathrm{PO}_{4}\right)_{6}(\mathrm{OH})_{2}[1,2]$. Of them, HA is more often used as it is the main inorganic component of bone tissue. It is produced in two ways: from native tissues yielding a biological (biogenic, bovine) hydroxyapatite (BHA) and in artificial conditions for a synthetic hydroxyapatite (SHA). The biocompatibility of both materials is at a rather high level, but in BHA, calcium, phosphorus, magnesium and other important trace elements are present in the same ionic forms and ratios as in the natural bone tissue. Moreover, variations in BHA stoichiometry are similar to those in bone apatite (1.3-1.7), which provides a more reactive medium for a balanced running of many physiological and biochemical processes required for the normal formation of bone tissue [3, 4].

The crystalline structure of apatites is stable and perfect, and similar phases are often considered as the most probable end product of many reactions. This explains the large number of apatite groups without impurities and synthetic compounds with various combinations of partial isomorphous substitutions [5, 6]. To provide HA based biomaterials with desired properties and to create multifunctional ceramics, composites are designed. Combination of different substances in a composite gives an effect equivalent to the creation of a new material whose properties qualitatively and quantitatively differ from the properties of each component 
[6]. It should be noted that in most of the investigated cases, even a slight change in the concentration of additives leads to significant changes in the physical and chemical properties of substances along with maintaining their overall structure nomination [7]. Iron $\left(\mathrm{Fe}^{2+}, \mathrm{Fe}^{3+}\right)$ [8-10] and its oxides [10, 11] are most often used as an X-ray-sensitive additives. It should also be noted that the biocompatibility of Fe oxides has been confirmed not only in experimental implantation, but also in studies of living organisms, in whose cells iron was found in the form of magnetite [12,13].

Methods for synthesis of $\mathrm{HA}$ and $\mathrm{Fe}_{3} \mathrm{O}_{4}$ have been described in numerous scientific papers, while synthesis of systems based on them has attracted far less attention [14]. In general, in the material $\mathrm{HA} / \mathrm{Fe}_{3} \mathrm{O}_{4}$ magnetite acts as a magnetically sensitive component with a reactive surface that allows realization of a chemical design and creation of the required multifunctional nanocomposite architecture, while HA acts as a thin-layer stabilizer [15]. The most commonly used method for synthesis of such composites is the production of individual components through their co-precipitation followed by uniting them using a hydrothermal method [8, 10, 16, 17]. The sol-gel method [18], biomimetic method [19, 20], methods of neutralization [21], ultrasound processing [22], and spray drying [23] are also used. In addition, there is a method that consists in introducing before-prepared magnetite in the form of powder or suspension directly in the course of HA synthesis [24]. The use of mechanical or mechano-chemical methods is less widespread. They include milling of separately synthesized suspensions or powders of magnetite and HA in ball or other mills. In this case, the $\mathrm{Fe}^{2+}$ and $\mathrm{Fe}^{3+}$ ions replace different positions of calcium in the crystal lattice of HA [25].

Taking into account the above information, the purpose of this work was to synthesize a composite system based on BHA and magnetite using described in the previous work two versions of the condensation physicochemical method [26] followed by heat treatment (thermolysis) in vacuum, hydrocarbon or nitrogen media and to establish the influence of the medium on the properties of the systems obtained.

\section{MATERIALS AND METHODS}

\subsection{Synthesis of composites}

As a starting material, pure BHA (bone tissue of cattle) "Osteoapatyt keramichny" ("Poputnyy Viter", Ukraine) was used. Doping BHA with ferromagnetic additives was performed using two procedures of the condensation physicochemical method described in [26]. The chemical method for preparation of a doped powder material consisted in introducing BHA directly in the process of obtaining an iron oxalate precipitate. First of all, the following reagents are prepared:

- $2.3 \mathrm{mg}$ of iron sulfate heptahydrate $\left(\mathrm{FeSO}_{4} \cdot 7 \mathrm{H}_{2} 0\right)$ and $6.4 \mathrm{~mL}$ of distilled water;

- $2.8 \mathrm{~mL}$ of isopropanol $\left(\mathrm{C}_{3} \mathrm{H}_{8} \mathrm{O}\right)$ with purity $99,8 \%$;

- $1.05 \mathrm{mg}$ of oxalic acid $\left(\mathrm{H}_{2} \mathrm{C}_{2} \mathrm{O}_{4} \cdot 2 \mathrm{H}_{2} \mathrm{O}\right)$ and $7 \mathrm{~mL}$ of distilled water;

- $0.56 \mathrm{~g}$ of sucrose $\left(\mathrm{C}_{12} \mathrm{H}_{22} \mathrm{O}_{11}\right)$ and distilled water in the amount required for the complete dissolution of the polysaccharide;

- suspension from $70 \mathrm{~g}$ of BHA and distilled water.

The solutions are cooled to $5-10{ }^{\circ} \mathrm{C}$ and poured out drop by drop in the above sequence under intense mixing for $2.5 \mathrm{~h}$. The resulting suspension settles for $3-4 \mathrm{~h}$. Then intense mixing and subsequent settling are repeated 3-4 times. An important condition for the production of iron oxalate nanoparticles is to strictly follow the above sequence of introductions of the reaction components. In this stage, the structure and specific properties of the particles are formed. Their uniform distribution in the material is an important factor, which is achieved by thoroughly mixing. It is worth mentioning that the formation of crystallization centers depends on the rate of mixing the solutions [27].

After filtration, the resulting BHA/iron oxalate material is dried in the air. In order to obtain the BHA/magnetite composite systems, the synthesized materials are subjected to heat treatment (low temperature thermolysis) in vacuum, hydrocarbon or nitrogen media for $2 \mathrm{~h}$ at $T=500{ }^{\circ} \mathrm{C}$ (below the Curie point $T_{c}$ for magnetite equal to $572^{\circ} \mathrm{C}$ ).

The method consists in deposition of ready iron oxalate onto the surface of the initial BHA particles in the form of hydrosuspension (Figure 1). The number of reagents was chosen based on the final amount of iron not more than 2 mass $\%$. 


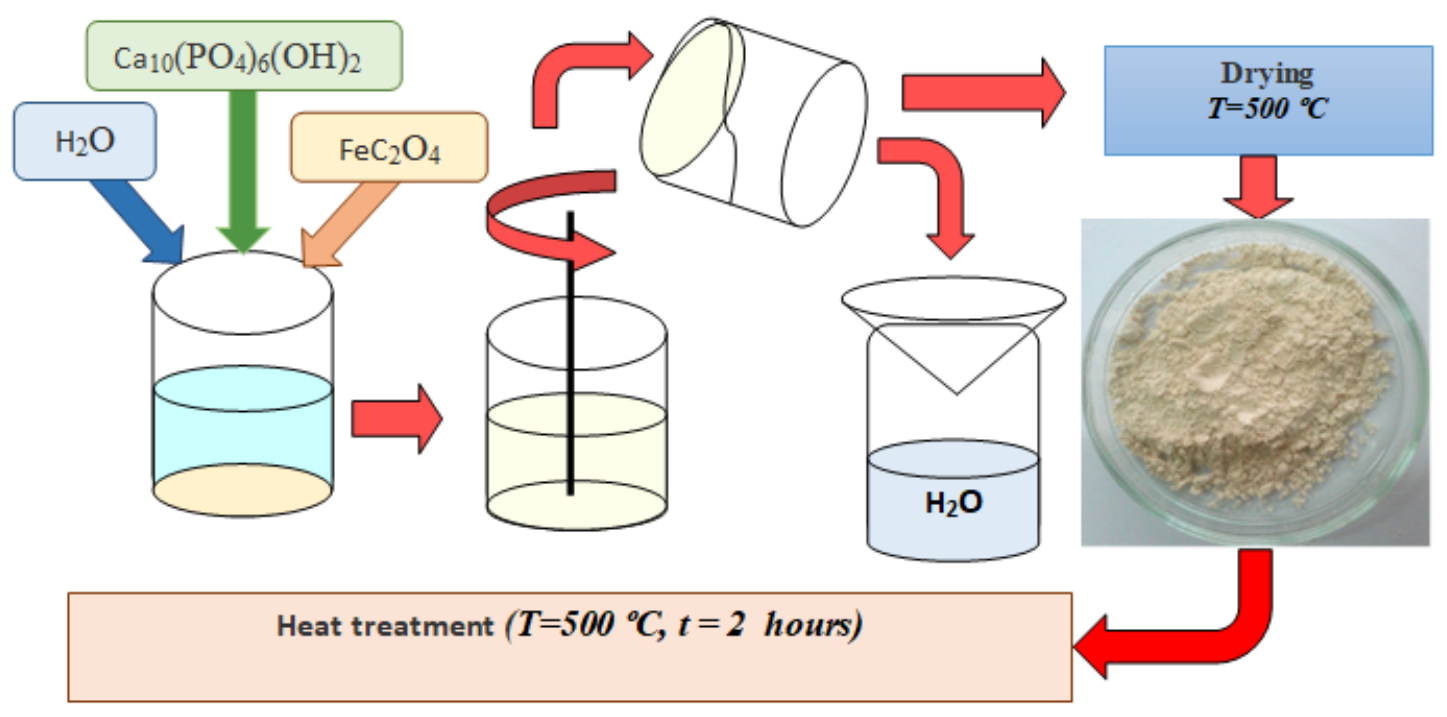

Figure 1: Technological scheme of sample preparation by the physico-mechanical method.

Subsequently, filtration dewatering and drying of the prepared dispersed system in were carried out. After that, the resulting material was thermally decomposed in a protective or a reducing medium under the above mentioned conditions.

\subsection{XRD analysis}

The phase composition was determined using an X-ray diffractometer "DRON 3.0" under the Co- $\mathrm{K}_{\alpha}$ radiation.

\subsection{Crystalline structure}

The width of the peak (002) at half its height (broadening FWHM) represents the size of the crystallites (area of coherent scattering) in the direction of the $c$ axis $\left(D_{c}\right)$ of the BHA crystalline lattice, whereas the peak (300) is related to the crystallite size in the direction of the $a$ axis $\left(D_{a}\right)$. Calculation of the sizes was performed using the Scherrer formula (1):

$$
D=\frac{k \cdot \lambda}{\beta \cdot \cos \theta}
$$

where $D$ is the size of crystallites, $\AA$; $k$ is the Scherrer constant (0.89), rad; $\lambda$ is the wave length of $\mathrm{X}$-ray radiation (1.7903 $\AA$ ); $\theta$ is the diffraction angle; $\beta=\sqrt{B^{2}-b^{2}}, \operatorname{rad}(B$ is the line broadening at half the peak intensity, while $b$ is the instrument-caused broadening).

Crystallinity $\left(X_{C}\right)$ of HA was calculated by the formula (2):

$$
X_{C}=1-\frac{v_{112 / 300}}{I_{300}}
$$

where $I_{300}$ is the intensity of the diffraction peak (300); $v_{112 / 300}$ is the intensity of the space between the (112) and (300) diffraction peaks [28].

\subsection{Chemical analysis}

The sample mass was measured on an analytical balance "OHAUS Pioneer PA214C" ("OHAUS Corporation", China) with an accuracy of $0.0001 \mathrm{~g}$. The iron, calcium and phosphorus contentsin the powders were determined by the photocalorimetric method [29] using an FEK-56M device (Russia): 
- the iron content in the powder materials was determined by the reaction of formation a yellow complex compound after chemical interaction of the sample and sulfosalicylic acid $\left(\mathrm{C}_{7} \mathrm{H}_{6} \mathrm{O}_{6} \mathrm{~S}\right)$ in ammonia $\left(\mathrm{NH}_{3}\right)$ medium [29];

- the total amount of phosphorus in solutions and powder materials was determined by method based on the formation of yellow phosphorus-molybdenum heteropolyacid with its subsequent restoration in hydrochloric medium by $\mathrm{Fe}^{2+}$ ions in the presence of hydroxylamine to formation of the complex compound of molybdenum blue [29];

- the calcium content of powders and filtration solutions was determined by the method with arsenazo I, where $\mathrm{Ca}^{2+}$ ions react with arsenazo I or neotorine in the basic medium $(\mathrm{pH}=12-13)$ to form the complex compound of red-violet color [29].

The total amount of carbon was determined with help of an "AN-7529" express analyzer (Belarus).

\subsection{Specific surface area}

The specific surface area of the powder biomaterials was determined by the thermal nitrogen desorption (BET method) using a sorbtometer "EMS-61" (Estonia).

\subsection{Morphological analysis}

The morphology of the particles of composites was studied using a scanning electron microscope (SEM) "JEOL Superprobe 733" in secondary electron imaging (SEI) mode.

\subsection{Magnetic properties}

The specific saturation magnetization was measured using a ballistic magnetometer at room temperature in magnetic fields up to $1 \mathrm{~T}(10 \mathrm{kE})[30]$.

\subsection{Experiments in vitro}

The investigation of specific mass loss was carried out in experiments in vitro by placing powders in an isotonic physiological $0.9 \% \mathrm{NaCl}$ ("Arterium", Ukraine) solution under the thermostatic conditions at a temperature similar to that of healthy human body $\left(36.5-37.0{ }^{\circ} \mathrm{C}\right)$ for 2,5 and 7 days. The solubility rate, as a characteristic of the specific mass loss, was determined by the formula (3):

$$
Q_{R}=\frac{\Delta m}{m_{o b} \cdot t} \cdot 100,
$$

where $\Delta m$ is the change in sample mass during the exposure to the model medium, $\mathrm{g} ; m_{o b}$ is the initial mass of the sample, $\mathrm{g}$; and $t$ is the time of the sample exposure to the model medium, days.

\section{RESULTS AND DISCUSSION}

\subsection{Chemical analysis}

The technological process of manufacturing any material includes a stage of control over the chemical composition. The data on the contents of iron and carbon in the investigated materials (Figure 2), as well as the values of the specific surface area are listed in Table 1. 


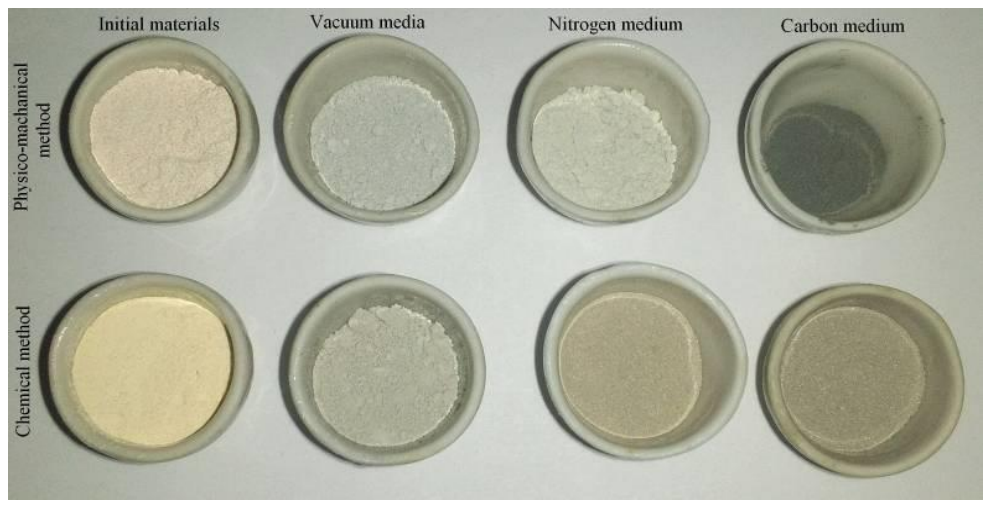

Figure 2: Initial materials and the composite after low temperature thermolysis in different media.

The chemical analysis findings presented in Table 1demonstrate the similarity of materials after low temperature thermolysis in a nitrogen medium and vacuum concerning the contents of both iron and carbon.

Table 1: Some physical and chemical characteristics of the samples studied.

\begin{tabular}{|c|c|c|c|c|}
\hline \multirow[t]{2}{*}{$\begin{array}{c}\text { MATERIAL } \\
\text { (METHOD OF } \\
\text { PRODUCTION) }\end{array}$} & \multirow[t]{2}{*}{$\begin{array}{c}\text { MEDIUM OF HEAT } \\
\text { TREATMENT, } \\
500 \stackrel{\circ}{ } \mathbf{2} \mathbf{h}\end{array}$} & \multirow[t]{2}{*}{$\begin{array}{c}\text { SPECIFIC SURFACE } \\
\text { AREA, } \\
\mathrm{m}^{2} / \mathrm{g}\end{array}$} & \multicolumn{2}{|c|}{$\begin{array}{c}\text { CONTENT OF } \\
\text { ELEMENTS, } \\
\text { mass } \%\end{array}$} \\
\hline & & & $\mathrm{Fe}$ & C \\
\hline BHA & - & 5.60 & 0.08 & 0.03 \\
\hline $\mathrm{BHA} / \mathrm{Fe}_{3} \mathrm{O}_{4}$ (phys.) & $\begin{array}{c}\text { Vacuum } \\
\left(1 \cdot 10^{-1} \mathrm{~mm} \mathrm{Hg}\right)\end{array}$ & 7.38 & 1.07 & 0.51 \\
\hline $\mathrm{BHA} / \mathrm{Fe}_{3} \mathrm{O}_{4}$ (chem.) & $\begin{array}{c}\text { Vacuum } \\
\left(1 \cdot 10^{-1} \mathrm{~mm} \mathrm{Hg}\right)\end{array}$ & 8.82 & 1.01 & 0.62 \\
\hline $\mathrm{BHA} / \mathrm{Fe}_{3} \mathrm{O}_{4}$ (phys.) & Nitrogen & 6.28 & 0.98 & 0.57 \\
\hline $\mathrm{BHA} / \mathrm{Fe}_{3} \mathrm{O}_{4}$ (chem.) & Nitrogen & 7.46 & 0.94 & 0.57 \\
\hline BHA/ $\mathrm{Fe}_{3} \mathrm{O}_{4}$ (phys.) & Hydrocarbon & 5.23 & 1.04 & 0.68 \\
\hline $\mathrm{BHA} / \mathrm{Fe}_{3} \mathrm{O}_{4}$ (chem.) & Hydrocarbon & 6.03 & 0.96 & 0.77 \\
\hline
\end{tabular}

According to the experimental studies in vivo by I.V. GURIN et al. [31], it is evident that the specified amount of carbon will not lead to a significant dystrophic-atrophic process in the case of implantation in an organism, since even purely carbonic materials do not cause cell infiltration both near the implant and throughout the visibility zone.

\subsection{XRD analysis}

According to the XRD data, powders obtained using the chemical method (Figure 3a) and then heat-treated in a vacuum contain some phases of the $\mathrm{Fe}-\mathrm{O}$ system. In this process, magnetite is reduced to iron, as indicated by the peak at $2 \theta \sim 51.8^{\circ}$. However, the magnetite $\left(\mathrm{Fe}_{3} \mathrm{O}_{4}\right)$ subjected to slight oxidation remains in the material, which is confirmed by the presence of hematite $\left(\mathrm{Fe}_{2} \mathrm{O}_{3}\right)$ traces on the XRD pattern. In comparison with other iron oxides, the test powder contains more wustite $(\mathrm{FeO})$ characterized by various $\mathrm{Fe} / \mathrm{O}$ ratios. 


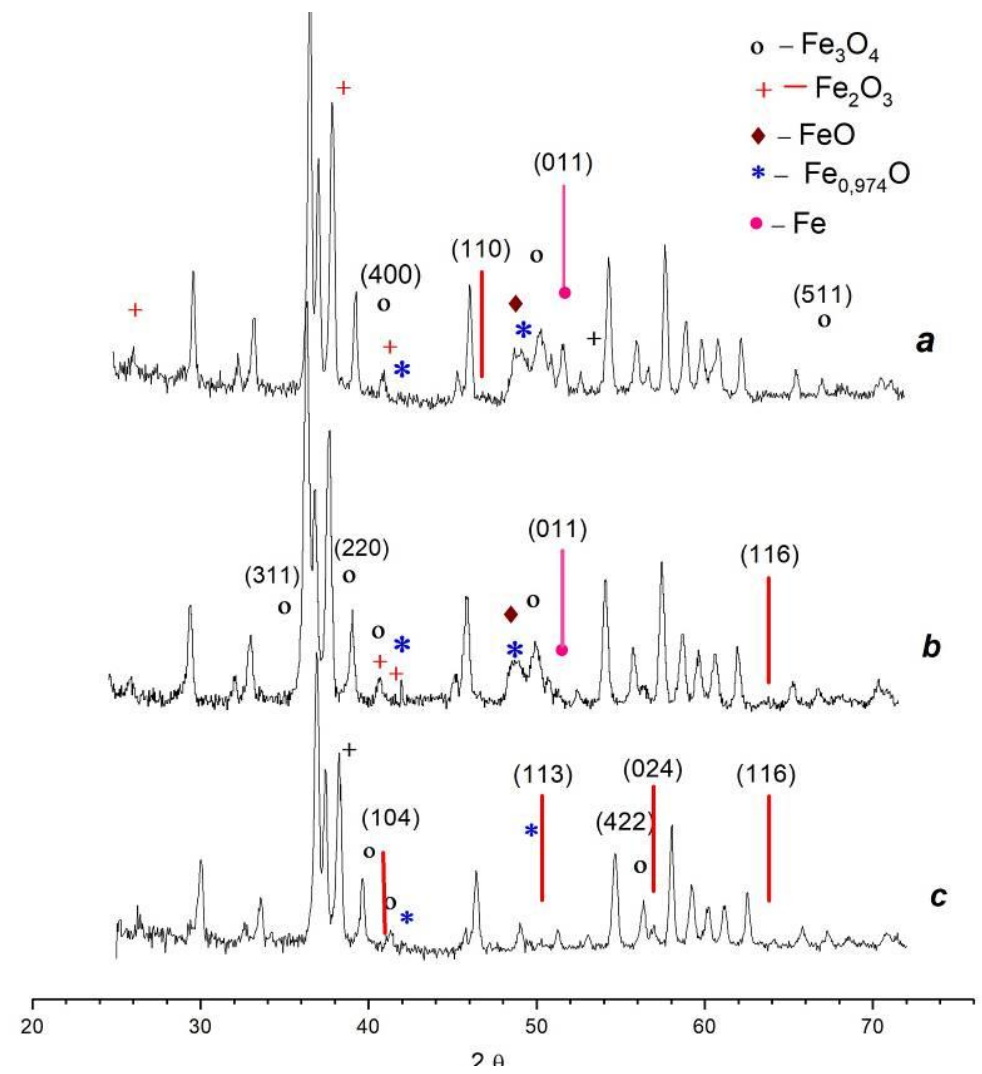

Figure 3: Fragments of the XRD patterns recorded from powdered samples obtained by the chemical method after heat treatment in $(a)$ vacuum, $(b)$ nitrogen and $(c)$ hydrocarbon media (with designation of the main peaks of the $\mathrm{Fe}-\mathrm{O}$ system phases).

The phase composition of the powder $\mathrm{BHA} / \mathrm{Fe}_{3} \mathrm{O}_{4}$ obtained by the chemical method and subjected to thermolysis in a nitrogen medium, is qualitatively similar to that of the powders after heat treatment in a vacuum. However, its XRD pattern (Figure $3 b$ ) is characterized by a significant decrease in the iron peak intensity and a slightly higher magnetite $\left(\mathrm{Fe}_{3} \mathrm{O}_{4}\right)$ oxidation.

The XRD patterns of the materials obtained by the chemical method and heat-treated in a hydrocarbon medium (Figure 3c) differs more markedly concerning iron-containing phases from the above described patterns (Figures $3 \mathrm{a}$ and $3 \mathrm{~b}$ ). It demonstrates the absence of the lines of iron oxides and pure iron at $2 \theta \sim$ $51^{\circ}$.Instead, there are observed the HA peaks only. At an angle of $2 \theta \sim 38.4^{\circ}$, an intense peak of hematite is singled out, that is, the magnetite oxidation and transformation of its large amount into hematite $\left(\mathrm{Fe}_{2} \mathrm{O}_{3}\right)$ occur. The wustite $\left(\mathrm{Fe}_{0.974} \mathrm{O}\right)$ peaks are also fixed. However, part of the magnetite $\left(\mathrm{Fe}_{3} \mathrm{O}_{4}\right)$ still remains in the material. In addition, when comparing this pattern with ones in Figs. $3 \mathrm{a}$ and $3 \mathrm{~b}$, one can see that the HA peaks are shifted toward the bigger angles. This indicates a decrease in the crystalline lattice parameters, presumably due to the replacement of calcium ions with iron ions.

The analysis of diffraction patterns of samples obtained by the physico-mechanical method after heat treatment in different media revealed the similarity of their phase composition to that of materials synthesized by the chemical method, which is confirmed by the fragments of diffraction patterns from powders obtained by different methods after heat treatment in a hydrocarbon medium (Figure 4). 


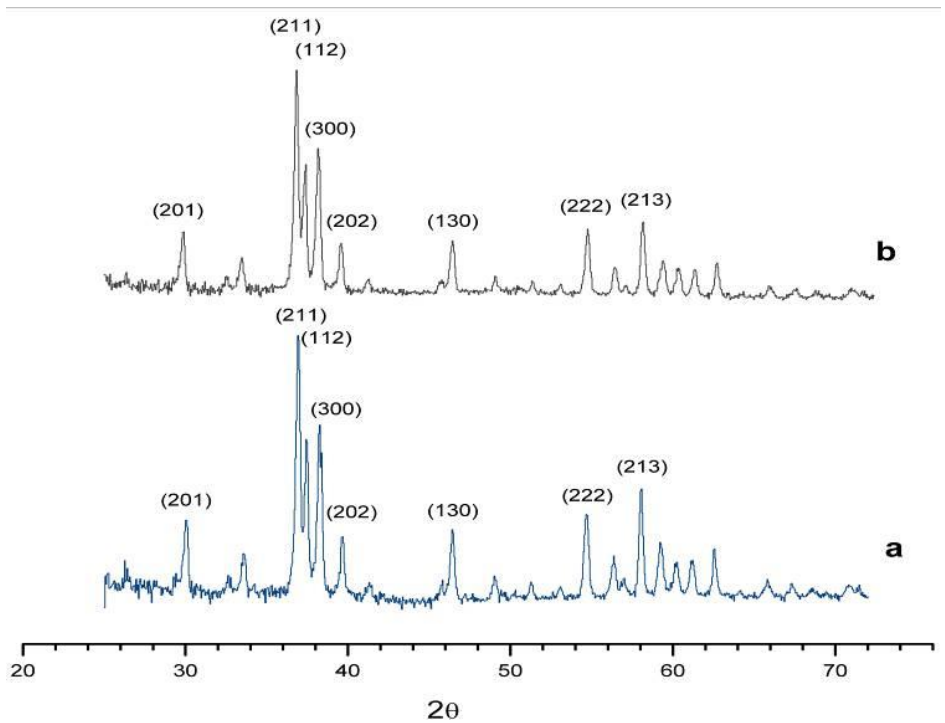

Figure 4: Fragments of the XRD patterns from the samples obtained by $(a)$ chemical and $(b)$ physico-mechanical methods after heat treatment in a hydrocarbon medium (with designation of the main HA peaks).

In other words, the peculiarities of the phase composition of the powders depend predominantly on the medium in which thermolysis takes place. The method for adding magnetite $\left(\mathrm{Fe}_{3} \mathrm{O}_{4}\right)$ has only a minor effect.

\subsection{Crystalline structure}

The crystalline structure of HA can be characterized by the crystallite sizes in the directions of the $a$ and $c$ axes, the crystallinity $H_{c}$, the crystalline lattice parameters, and the crystalline cell volume. The results of calculations performed to characterize the state of the HA crystalline structure are presented in Table 2.

Table 2: Some characteristics of the HA crystalline structure in the powdered samples studied.

\begin{tabular}{|c|c|c|c|c|c|}
\hline $\begin{array}{c}\text { MATERIAL } \\
\text { (METHOD OF } \\
\text { PRODUCTION) }\end{array}$ & $\begin{array}{c}\text { MEDIUM OF } \\
\text { HEAT } \\
\text { TREATMENT, } \\
500 \stackrel{\circ}{ } \text {, } 2 \text { h } \\
\end{array}$ & $\begin{array}{c}\text { CRYSTALLITE } \\
\text { SIZE } D_{c} \\
\text { ALONG } c \text { AXIS } \\
(\mathrm{nm}) \\
\end{array}$ & $\begin{array}{c}\text { CRYSTALLITE } \\
\text { SIZE } D_{a} \\
\text { ALONG aAXIS } \\
(\mathrm{nm}) \\
\end{array}$ & $\begin{array}{c}\text { DEGREE } \\
\text { OFCRYSTALLINITY } \\
(\%)\end{array}$ & $\begin{array}{c}\text { VOLUME } \\
\text { OFCRYSTALLINE } \\
\text { CELL }\left(\AA^{3}\right)\end{array}$ \\
\hline $\begin{array}{c}\mathrm{BHA} / \mathrm{Fe}_{3} \mathrm{O}_{4} \\
\text { (chem.) }\end{array}$ & Hydrocarbon & 69.5 & 39.5 & 76 & 533.7 \\
\hline $\begin{array}{c}\mathrm{BHA} / \mathrm{Fe}_{3} \mathrm{O}_{4} \\
\text { (phys.-mech.) }\end{array}$ & Hydrocarbon & 64.1 & 42.2 & 77 & 537.8 \\
\hline $\begin{array}{c}\mathrm{BHA} / \mathrm{Fe}_{3} \mathrm{O}_{4} \\
\text { (chem.) }\end{array}$ & Nitrogen & 44.6 & 36.8 & 79 & 537.0 \\
\hline $\begin{array}{c}\mathrm{BHA} / \mathrm{Fe}_{3} \mathrm{O}_{4} \\
\text { (phys.-mech.) }\end{array}$ & Nitrogen & 61.0 & 34.5 & 71 & 534.3 \\
\hline $\begin{array}{c}\mathrm{BHA} / \mathrm{Fe}_{3} \mathrm{O}_{4} \\
\text { (chem.) }\end{array}$ & $\begin{array}{c}\text { Vacuum } \\
\left(1 \cdot 10^{-1} \mathrm{~mm} \mathrm{Hg}\right)\end{array}$ & 45.5 & 49.5 & 86 & 537.5 \\
\hline $\begin{array}{c}\mathrm{BHA} / \mathrm{Fe}_{3} \mathrm{O}_{4} \\
\text { (phys.-mech.) }\end{array}$ & $\begin{array}{c}\text { Vacuum } \\
\left(1 \cdot 10^{-1} \mathrm{~mm} \mathrm{Hg}\right)\end{array}$ & 55.1 & 40.2 & 81 & 535.9 \\
\hline BHA initial & - & 82.5 & 49.5 & 70 & 532.4 \\
\hline
\end{tabular}

The most vivid change in the state of the HA crystalline lattice is reflected in the change in the degree of HA crystallinity. The above presented data allow us to assert that the most perfect lattice is formed with the use of the chemical method for production and heat treatment in a vacuum (crystallinity $86 \%$ ), and the least perfect one is formed by the physico-mechanical method for production and heat treatment in a 
nitrogen medium (71\%).

The elementary cell volume is related to both the presence of vacancies and the size of the ions present in its composition. In the case of replacing calcium ions with iron ions, the lattice parameters are expected to decrease, while the absence of vacancies will increase them.

The volume of the HA crystalline cell in composites obtained by the chemical method is the biggest after heat treatment in a vacuum. At the same time, the corresponding XRD pattern contains a fairly significant peak of iron (Fig. 3a). On the contrary, after treatment in a hydrocarbon medium, the iron peak is absent, and the cell volume is the smallest. It is likely that some iron atoms replace the calcium ions in HA crystals. Treatment in a nitrogen medium gives intermediate values. In the case of using the physico-mechanical method for production, the conditions of interaction of HA with other substances change and a maximum volume is achieved after treatment in a hydrocarbon medium.

The difference between the cell volumes depending on the procedure for introducing magnetite $\left(\mathrm{Fe}_{3} \mathrm{O}_{4}\right)$ is the biggest after treatment in a hydrocarbon medium. In this case, more stable results can be obtained after the use of a vacuum medium. The smallest crystallite sizes in the direction of the $a$ axis are obtained for a nitrogen medium, where as they in the $c$ axis direction are characteristic for a vacuum heat treatment.

\subsection{Morphological analysis}

The morphological analysis was carried out because surface topology of biomaterials and their porosity are important factors for osteogenesis during bone regeneration. It is mandatory for biomaterials to have pores of $100-200 \mu \mathrm{m}$ in size, which are required for normal circulation of blood and other physiological fluids around it after implantation [32]. The partical size of such biomaterials varies from $20 \mathrm{~nm}$ to $100 \mu \mathrm{m}$ [33].

According to the SEM data, the initial BHA powder consists of 2-12 $\mu \mathrm{m}$ agglomerates formed by spherical nanoparticles with a diameter of less than $1 \mu \mathrm{m}(\sim 280-670 \mathrm{~nm})$ and commensurate pores (Figures $5 A$ and $5 E)$.
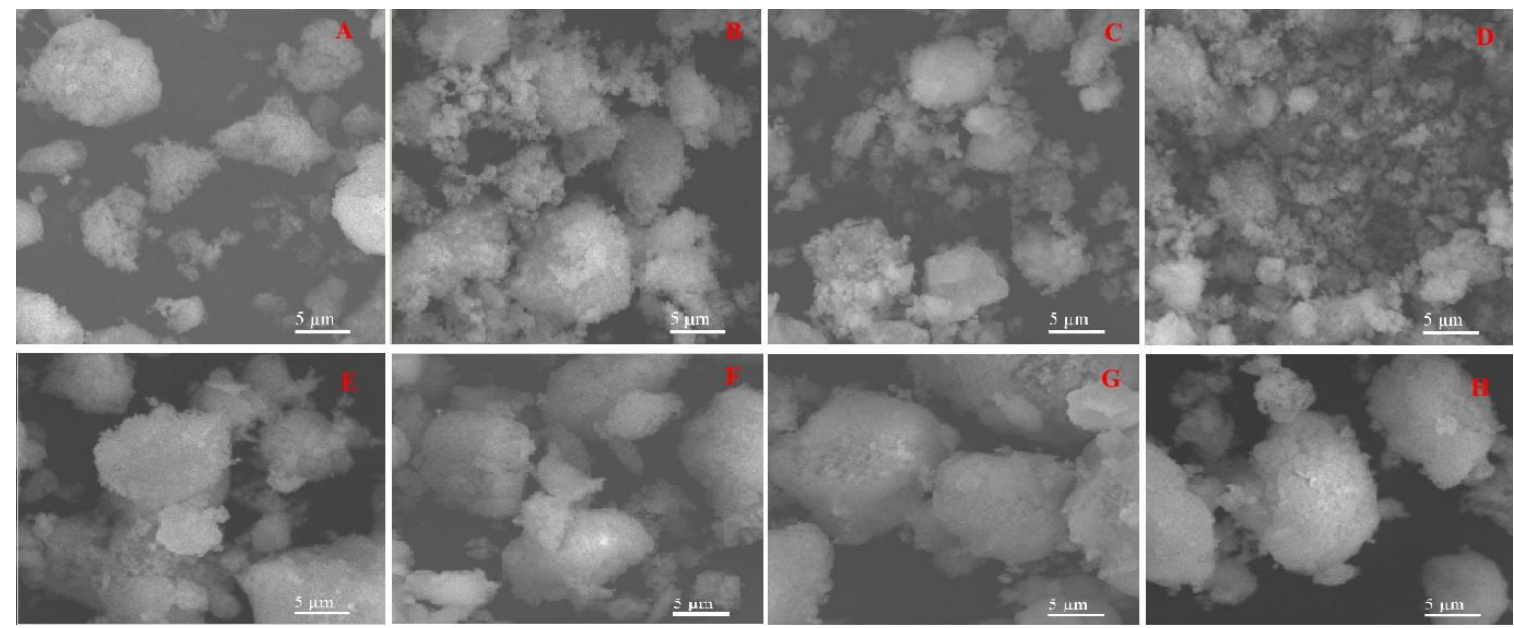

Figure 5: SEM micrographs of the initial BHA $(A, E)$; composite systems $\mathrm{BHA} / \mathrm{Fe}_{3} \mathrm{O}_{4}$ obtained by the physicomechanical method after heat treatment in vacuum $(B)$, nitrogen medium $(C)$, and hydrocarbon medium $(D)$; composite systems $\mathrm{BHA} / \mathrm{Fe}_{3} \mathrm{O}_{4}$ obtained by the chemical method after heat treatment in vacuum $(\mathrm{F})$, nitrogen medium (G) and hydrocarbon medium (H). Magnification X3000.

As can be seen in Figure 5, the physico-mechanical method makes it possible to obtain a larger variation in the size of agglomerates: from preferably $2.8-5.6 \mu \mathrm{m}$ for heat treatment in a hydrocarbon medium (Figure $5 D$ ) to $6.4-11.5 \mu \mathrm{m}$ for a vacuum (Figure $5 B$ ). Treatment in a nitrogen medium (Figure $5 C$ ), where the size of agglomerates is preferably 7.8-8.6 $\mu \mathrm{m}$ and there are many smaller 3-6 $\mu \mathrm{m}$ formations of various shapes, yields intermediate results. However, one can also observe certain similarities, in particular in the sphericity of particles that form large agglomerates and smaller aggregates of irregular shape, which averages 140-700 $\mathrm{nm}$. Large agglomerates after heat treatment in a vacuum contain pores sizing within 140-200 nmand sometimes below $120 \mathrm{~nm}$. After heat treatment in nitrogen and hydrocarbon media, the pore sizes in agglomerates fall in the range $130-250 \mathrm{~nm}$.

In the case of using the chemical method to obtain the $\mathrm{BHA} / \mathrm{Fe}_{3} \mathrm{O}_{4}$ composites, regardless of theirtreatment medium, the presence of predominantly large agglomerates of particles is characteristic. After thermolysis in a vacuum (Figure $5 F$ ), 4.3-16.0 $\mu$ m formations are observed, which consist of spherical and 
rounded $150-420 \mathrm{~nm}$ particles and $100-150 \mathrm{~nm}$ pores.

Microphotographs of powders after heat treatment in nitrogen (Figure $5 G$ ) and hydrocarbon (Figure $5 H$ ) media show similar results. They are characterized by the presence of $12-21.5 \mu \mathrm{m}$ agglomerates formed by particles of predominantly spherical shape with a diameter of most 600-700 nm or less. Noticeable in the structure of such particles are pores sizing within $200-650 \mathrm{~nm}$.

Hence, be reasoned that the chemical method preserved the structure of initial materials regardless of the heat treatment mediums. According to the data on the Figure 5 could argue that the studied materials have a sufficient porosity needed to a drug adsorption and proliferation of biological cells.

\subsection{Magnetic properties}

The above results are confirmed by the findings for the specific saturation magnetization of the studied materials (Figure 6), which are on the lower limit of the capabilities of the used ballistic magnetometer $(0.1 \mathrm{~A}$ $\mathrm{m}^{2} / \mathrm{kg}$ ) and do not exceed $1 \mathrm{~A} \mathrm{~m}^{2} / \mathrm{kg}$, which indicates a low content of magnetite.

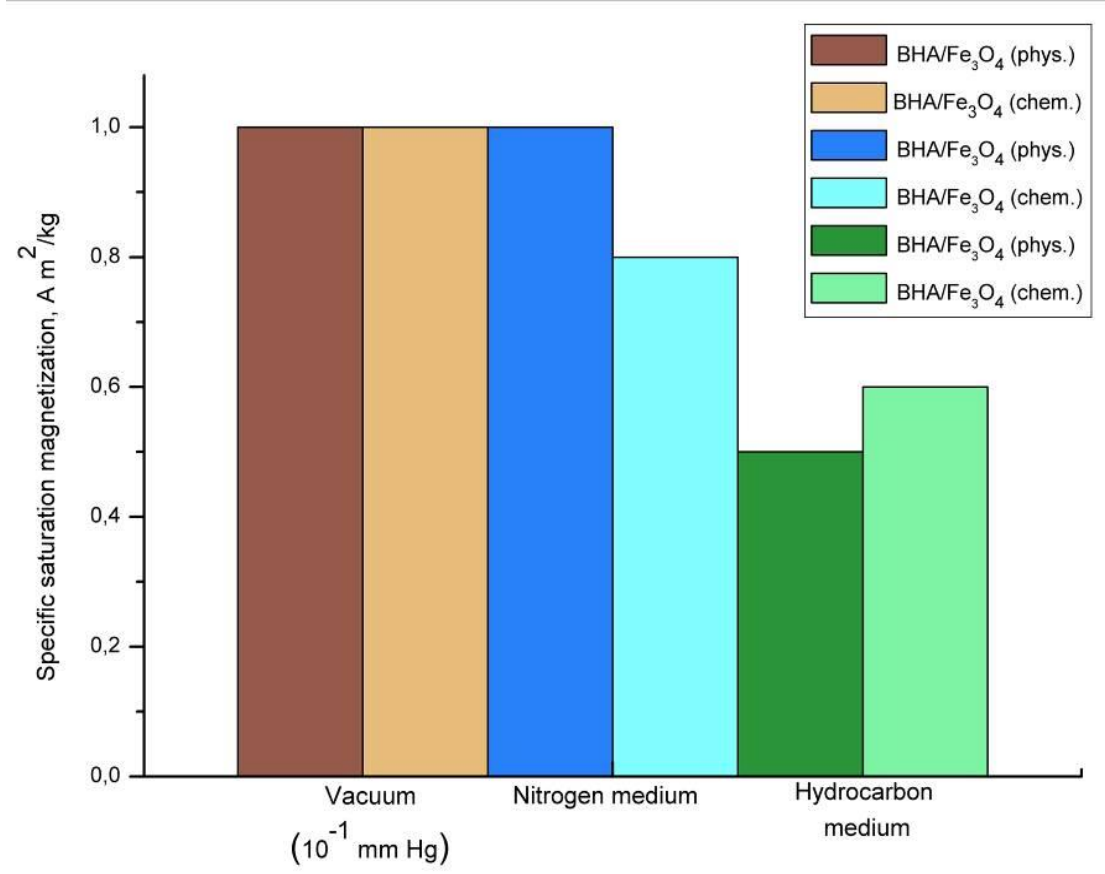

Figure 6: Specific saturation magnetization of the $\mathrm{BHA} / \mathrm{Fe}_{3} \mathrm{O}_{4}$ composites under study.

\subsection{Experiments in vitro}

The probable behavior of $\mathrm{BHA}$ and $\mathrm{BHA} / \mathrm{Fe}_{3} \mathrm{O}_{4}$ in an antibiotic solution can before seen via determining their bioresorption in experiments in vitro using an analogical dissolvent. For this, the powders were placed in an isotonic physiological $0.9 \% \mathrm{NaCl}$ ("Arterium", Ukraine) solution for 2, 5 and 7 days at a temperature equal to that of healthy human body $\left(36.5-37.0^{\circ} \mathrm{C}\right)$. The obtained results are shown in Figure 7. Looking back to the data of Table 1, could argue that the results of bioresorption are consequence from the difference between the specific surface areas of studied samples: bioresorption value is directly proportional to the value of specific surface area. 


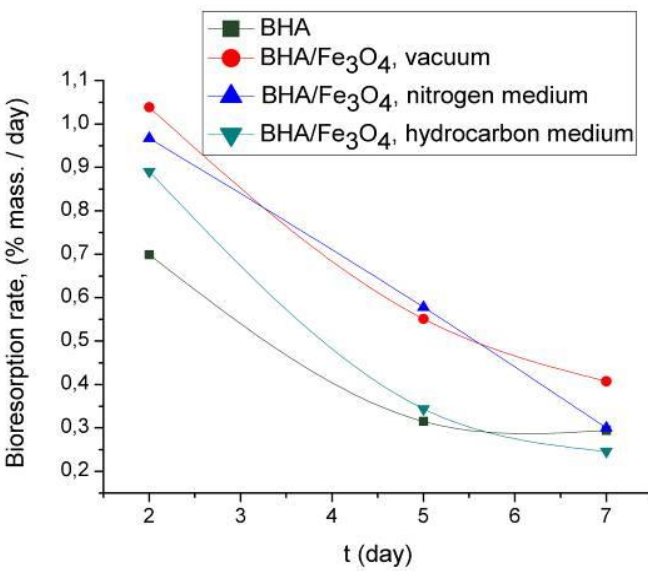

Chemical method

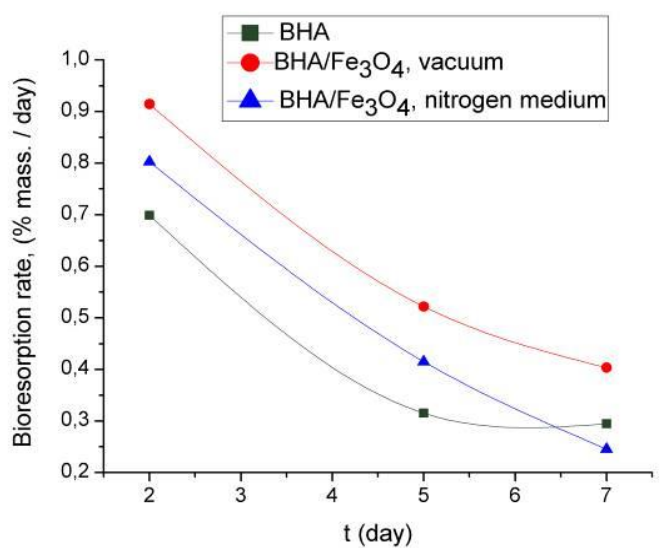

Physicomechanical method

Figure 7: Bioresorption rate of the studied powders $(n=10)$.

The chemical analysis of the filtrates (Table 3) showed a uniform increase in the content of calcium ions along with a uniform decrease in the content of phosphate ions during the experiment. The maximum concentration of iron ions was fixed in the first two days followed by a sharp decrease. Such results can be attributed to the presence of a significant number of negatively charged ions $(\mathrm{Cl}, \mathrm{OH})$ and compounds of the basic nature, in particular $\mathrm{Ca}(\mathrm{OH})_{2}, \mathrm{Fe}(\mathrm{OH})_{2}$ and/or $\mathrm{Fe}(\mathrm{OH})_{3}$ in all filtrates.

Table3:Results of the chemical analysis of filtrates after in vitro experiments.

\begin{tabular}{|c|c|c|c|c|c|}
\hline \multirow{2}{*}{$\begin{array}{c}\text { MATERIAL } \\
\text { (METHOD OF } \\
\text { PRODUCTION) }\end{array}$} & \multirow{2}{*}{$\begin{array}{c}\text { MEDIUM OF HEAT } \\
\text { TREATMENT, } \\
500 \stackrel{\circ}{ } \mathbf{2} \mathbf{~ h}\end{array}$} & \multirow{2}{*}{$\begin{array}{c}\text { DURATIONOF } \\
\text { EXPERIMENT } \\
\text { (days) }\end{array}$} & \multicolumn{3}{|c|}{$\begin{array}{l}\text { CONTENT OF ELEMENTS } \\
(\mathbf{m g})\end{array}$} \\
\hline & & & $\mathrm{Ca}$ & $\mathbf{P}$ & $\mathrm{Fe}$ \\
\hline \multirow[t]{3}{*}{$\mathrm{BHA} / \mathrm{Fe}_{3} \mathrm{O}_{4}$ (phys.) [34] } & Vacuum & 2 & 0.37 & 0.019 & 0.098 \\
\hline & $\left(1 \cdot 10^{-1} \mathrm{~mm} \mathrm{Hg}\right)$ & 5 & 0.32 & 0.013 & 0.011 \\
\hline & & 7 & 0.55 & 0.015 & 0.017 \\
\hline \multirow[t]{3}{*}{$\mathrm{BHA} / \mathrm{Fe}_{3} \mathrm{O}_{4}$ (chem.) [34] } & Vacuum & 2 & 0.46 & 0.019 & 0.081 \\
\hline & $\left(1 \cdot 10^{-1} \mathrm{~mm} \mathrm{Hg}\right)$ & 5 & 0.35 & 0.006 & 0.010 \\
\hline & & 7 & 0.70 & 0.018 & 0.017 \\
\hline \multirow[t]{3}{*}{$\mathrm{BHA} / \mathrm{Fe}_{3} \mathrm{O}_{4}$ (phys.) } & Nitrogen & 2 & 0.31 & 0.018 & 0.100 \\
\hline & & 5 & 0.32 & 0.009 & 0.050 \\
\hline & & 7 & 0.46 & 0.006 & 0.010 \\
\hline \multirow[t]{3}{*}{$\mathrm{BHA} / \mathrm{Fe}_{3} \mathrm{O}_{4}$ (chem.) } & Nitrogen & 2 & 0.47 & 0.019 & 0.089 \\
\hline & & 5 & 0.59 & 0.018 & 0.043 \\
\hline & & 7 & 0.67 & 0.018 & 0.014 \\
\hline \multirow[t]{3}{*}{$\mathrm{BHA} / \mathrm{Fe}_{3} \mathrm{O}_{4}$ (chem.) } & Hydrocarbon & 2 & 0.41 & 0.017 & 0.073 \\
\hline & & 5 & 0.47 & 0.011 & traces \\
\hline & & 7 & 0.52 & 0.003 & traces \\
\hline
\end{tabular}

Probably, during the experiment the number of these compounds is varying: after the first two days, the solutions contain a minimum amount of $\mathrm{Ca}(\mathrm{OH})_{2}$ and a maximum level of $\mathrm{Fe}(\mathrm{OH})_{2}$, while on the $7^{\text {th }}$ day the amount of $\mathrm{Ca}(\mathrm{OH})_{2}$ increases and the level of $\mathrm{Fe}(\mathrm{OH})_{2}$ becomes minimal. A slight decrease in $\mathrm{pH}$ over time for all samples is due to the decrease in the content of phosphate ions and the $\mathrm{OH}^{-}$groups owing to the formation of insoluble $\mathrm{Ca}_{3}\left(\mathrm{PO}_{4}\right)_{2}, \mathrm{Fe}(\mathrm{OH})_{2}$ and/or $\mathrm{Fe}(\mathrm{OH})_{3}$ compounds. In particular, powders obtained by the chemical method and heat treated in a vacuum [34] and nitrogen medium are characterized by a decrease in $\mathrm{pH}$ from 8.4 for 2 days to 8.2 for 7 days, while $\mathrm{pH}$ of the sample treated in a hydrocarbon medium lowered from 8.3 to 8.1 . Powder biomaterials obtained by the physico-mechanical method are characterized by $\mathrm{pH}$ decrease from 8.6 for 2 days to 8.4 for 7 days in the case of heat treatment in a vacuum [34] and from 8.6 to 
8.3 for a nitrogen medium.

It is worth noting that the results presented in Table 3 are consistent with the data in Figure 7 and the $\mathrm{pH}$ values for the filtrates.

\section{CONCLUSIONS}

The $\mathrm{BHA} / \mathrm{Fe}_{3} \mathrm{O}_{4}$ composites were synthesized using two methods (chemical and physicomechanical) combined with subsequent heat treatment in vacuum, nitrogen and hydrocarbon media. The obtained results showed that the most efficient method for obtaining the BHA/iron oxalate material is the chemical method, and an optimal medium for its heat treatment to produce the $\mathrm{BHA} / \mathrm{Fe}_{3} \mathrm{O}_{4}$ composite is a vacuum. Despite the magnetite $\left(\mathrm{Fe}_{3} \mathrm{O}_{4}\right)$ dominant oxidation to hematite $\left(\mathrm{Fe}_{2} \mathrm{O}_{3}\right)$ and partial reduction to wustite $(\mathrm{FeO})$, these conditions provide a more perfect crystalline structure (crystallinity 86\%) compared to the other materials studied. In addition, $\mathrm{BHA} / \mathrm{Fe}_{3} \mathrm{O}_{4}$ (chem.) exhibited the highest values of specific saturation magnetization and a stable behavior in experiments in vitro.

\section{ACKNOWLEDGMENTS}

The authors grateful to O. Budylina and L. Protsenko (Frantsevich Institute for Problems of Materials Science), for help in the investigation of chemical analisys of the studied powders and their filtrates; and Dr. I.Uvarova (Frantsevich Institute for Problems of Materials Science) for help in the interpretation of single results presented in this article.

\section{BIBLIOGRAPHY}

[1] DOROZHKIN, S.V., "Calcium orthophosphate bioceramics", Ceramics International,v. 41, n. 10, pp. 13913-13966, Dec. 2015.

[2] BEADMAN, F.D, BANCROFT, L.W., PETERSON, J.J, et al., "Bone graft materials and synthetic substitutes", Radiologic Clinics of North America, v. 44, n. 3, pp. 451-461, May 2006.

[3] MISHRA, A., KHOBRAGADE, N., SIKDAR, K., et al., "Study of Mechanical and Tribological Properties of Nanomica Dispersed Hydroxyapatite Based Composites for Biomedical Applications", Advances in Materials Science and Engineering, e9814624, doi:10.1155/2017/9814624, Feb. 2017.

[4] MESTRES, G., ESPANOL, M., XIA, W., et al., "Inflammatory Response to Nano and Microstructured Hydroxyapatite", PLoS ONE, v. 10, n. 4, e0120381, https://doi.org/10.1371/journal.pone.0120381, Apr. 2015.

[5] KURGAN, N., KARBIVSKYY, V., KASYANENKO, V., "Morphology and electronic structure of nanoscale powders of calcium hydroxyapatite", Nanoscale Research Letters, v. 10, n. 41, eCollection 2015. doi: 10.1186/s11671-015-0770-1, Feb. 2015.

[6] KOLMAS, J., GROSZYK, E., PIOTROWSKA, U., "Nanocrystalline hydroxyapatite enriched in selenite and manganese ions: physicochemical and antibacterial properties", Nanoscale Research Letters, v. 10, n. 1, doi: 10.1186/s11671-015-0989-x, Dec. 2015.

[7] DANYLCHENKO, S.N., "Structure and properties of calcium apatites from point of view the mineralogy and biomaterial sciences (Review)", Vestnik SumSU: Physics, Mathematics, Mechanics, n. 2, pp. 33-59, Jun. 2007 [in Russian].

[8] KI, YA., NAM. S.T., OOI, C.P., et al., "Iron (III) and Manganese (II) Substituted Hydroxyapatite Nanoparticles: Characterization and Cytotoxicity Analysis", Journal of Physics: Conference Series, n. 187, pp.1-8, Sep. 2009.

[9] RAU, J.V., CACCIOTTI, I., DE BONIS, A., et al., "Fe-doped hydroxyapatite coatings for orthipedic and dental implant application", Applied Surface Science, n. 307, pp. 301-308, Jul. 2014.

[10] LI, Q., ZHOU, G., WANG, T., et al., "Investigations into the Biocompatibility of Nanohydroxyapatite Coated Magnetic Nanoparticles under Magnetic Situation", Journal of Nanomaterials, doi: 10.1155/2015/835604, Dec. 2015.

[11] FARZIN, L., SHAMSIPUR, M., "Separation and preconcentration of riboflavin from human plasma using polythionine coated magnetite/hydroxyapatite nanocomposite prior to analysis by surfactant-enhanced fluorimetry", Spectrochimica Acta Part A: Molecular and Biomolecular Spectroscopy, n. 184, pp. 109-118, Sep. 2017.

[12] WILliS, A.L., TURRO, N.J., O’BRIEN, S., "Spectroscopic Characterization of the Surface of Iron Oxide Nanocrystals", Chemical Materials, v. 17, n. 24, pp. 5970-5975, Nov. 2005.

[13] GOROBETS, S.V, GOROBETS, O.Y., "Function of biogenic magnetic nanoparticles in organisms", 
Functional Materials, v. 19, n. 1, pp. 18-26, Jan. 2012.

[14] MONDAL, S., MANISAVAGAN, P., BHARATHIRAJA, S., et al.,"Magnetic Hydroxyapatite: a promising multifunctional platform for nanomedicine application", International Journal of Nanomedicine, $\mathrm{n}$. 12, pp. 8389-8410, Nov. 2017.

[15] OTYCHENKO, O.M, BABUTINA T.YE., KUDA, O.A., et al., “Adsorption of ceftriaxon by biogenic hydroxyapatite with magnetic additions”, Functional Materials, v. 24, n. 4, pp. 577-583, Dec. 2017.

[16] TRAN, N., WEBSTER, T.J., "Increased Osteoblast Functions in the Presence of Hydroxyapatite-Coated Iron Oxide Nanoparticles”, Acta Biomaterialia, v.7, n. 3, pp. 1298-1306, Mar. 2011.

[17] OKUDA, M., TAKEGUCHI, M., RUAIC, O.O., et al., "Structural analysis of hydroxyapatite coating on magnetite nanoparticles using energy filter imaging and electron tomography", Journal of Electron Microscopy, v. 59, n. 2, pp. 173-179, Nov. 2009.

[18] KAYGILI, S.V., DOROZHKIN, S.V., ATES, T., et al., "Dielectric properties of Fe doped hydroxyapatite prepared by sol-gel method", Ceramics International, v. 40, n. 7, pp.9395-9402, Aug. 2014.

[19] MUZQUIZ-RAMOS, E.M., CORTES-HERNANDEZ, D.A., ESCOBEDO-BOCARDO, J., "Biomimetic apatite coating on magnetite particles", Materials Letters, v. 64, n. 9, pp. 1117-1119, May 2010.

[20] YABUTSUKA, T., YAO, T., "Preparation of encapsulated magnetite microparticles with hydroxyapatite", Energy Procedia, n. 9, pp.532-538, Sep. 2011.

[21] TAMPIERI, A., D’ALESSANDRO, T., SANDRI, M., et al., "Intrinsic magnetism and hyperthermia in bioactive Fe-doped hydroxyapatite”, Acta Biomaterialia, v. 8, n. 2, pp. 843-851, Feb. 2012.

[22] GOPI, D., ANSARI M.T., SHINYJOY, E., et al., "Synthesis and spectroscopic characterization of magnetic hydroxyapatite nanocomposite using ultrasonic irradiation", Spectrochimica Acta Part A: Molecular and Biomolecular Spectroscopy, v. 8, pp. 245-250, Feb. 2012.

[23] DONADEL, K., FELISBERTO, M.D.V., LARANJEIRA, M.C.M., "Preparation and characterization of hydroxyapatite-coated iron oxide particles by spray-drying technique", Anais da Academia Brasileira de Ciências, v. 81, n. 2, pp. 179-186, June 2009.

[24] DONG, L., ZHU, Z., QUI, Y., et al., "Removal of lead from aqueous solution by hydroxyapatite/magnetite composite adsorbent”, Chemical Engineering Journal, v. 165, n. 3, pp. 827-834, Dec. 2010.

[25] OTYCHENKO, O.M., PINCHUK, N.D., PARKHOMEY, O.R., et al., "Effect of Preliminary Magnetic Treatment on Dynamics Dissolubility of Composition Hydroxyapatite Material", Nanostructured Materials Science, n. 2, pp. 45-52, Jul. 2014 [in Ukrainian].

[26] OTYCHENKO, O.M., BABUTINA T.E., PARKHOMEY O.R., et al., "Influence of thermolysis in the nitrogen medium on physicochemical properties of medical using material based on biogenic hydroxyapatite”, Chemistry, Physics and Technology of Surface, v. 8, n. 1, pp. 10-17, Jan. 2017.

[27] KUSCHEVSKA, N.F., SHVETS, T.M., MAKSYMENKO, T.S., "Method for obtaining a fine iron powder". UA Patent 26584 (October, 1999).

[28] YACOUBI, A.E., MASSIT, A., FATHI, M., et al., "Characterization of silicon-substituted hydroxyapatite powders synthesized by a wet precipitation method", Journal of Applied Chemistry, v. 7, n. 11, pp. 2429, Nov. 2014.

[29] ZOLOTOV Yu.A., Analytical chemistry (Book 2). Chemical analysis methods, Moscow, Russian Federation, Vysshaya shkola, 2002 [in Russian].

[30] BOROVYK, E.S., EREMENKO, V.V., MILNER, A.S., Lectures on Magnetism, Moscow, Russian Federation, Fizmatlit, 2005 [in Russian].

[31] GURIN, I.V., VVEDENSKIY, B.P., GURIN, V.A., et al., "Obtaining long catalytic carbon formations and the investigation of their biological compatibility", Biotehnologia, v. 4, n. 2, pp. 54-60, Jun. 2011 [in Russian].

[32] DENRY I., Kuhn L.T., "Design and characterization of calcium phosphate ceramics scaffolds for bone tissue engineering", Dental Materials, n. 32, pp. 43-53, 2017.

[33] PANSERI S., CUNHA C., D’ALESSANDRO T., et al., "Magnetic Hydroxyapatite Substitute to Enhance Tissue Regeneration: Evaluation In vitro Using Osteoblast' Like Cells and In vivo in a Bone Defect, PLOS ONE, v. 7, I. 6, pp. 1-8, Des. 2012.

[34] OTYCHENKO, O.M., BABUTINA, T.Y., ZIATKEVICH, D.P., et al., "Some physico-mechanical properties of composite biomaterials on the basis of biogenic hydroxyapatite with magnetic additives ", Functional Materials, v. 25, n. 4, pp. 695-701, Dec. 2018. 
ORCID

Oksana Otychenko Tetyana Babutina Anatolii Perekos Oleksandr Bykov Sergiy Korichev

Oleksandr Koval https://orcid.org/0000-0001-9210-1738

https://orcid.org/0000-0002-6927-2595

https://orcid.org/0000-0002-1669-2342

https://orcid.org/0000-0001-6959-3498

https://orcid.org/0000-0003-2689-3129

https://orcid.org/0000-0003-0315-5190 